\title{
Development of Lesson Plan (LP) with Software Lectora Inspire Assisted Problem-Based Learning in Improving Learning Outcomes for Senior High School.
}

\author{
Achmad Aswal*, Hunaidah, and Erniwati \\ Department of Physics Education, University of Halu Oleo \\ Street H.E.A Mokodompit, Kendari, Indonesia 93231 \\ Email: ${ }^{*}$ aswalachmad@gmail.com
}

\begin{abstract}
This research-based on technological advances that promote the use of technology in learning, on the lack of valid, practical and effective lesson plans, particularly in problem-based learning models that are in line with the 2013 curriculum, and on the use of Lectora Inspire Software in the creation of lesson plans. This study was conducted to develop problem-based learning model based on Lectora Inspire software. This type of research is research and development (research and development). The design of this study based on five out of ten phases of Borg and Gall's research design, namely research and collection of initial information, planning, development of original product formats, initial testing and product improvement. The effectiveness test results were rated very well with an average of $88 \%$ and $89.04 \%$. The increase (n-gain) of student learning outcomes is 0.62 which can be categorized as a moderate increase.
\end{abstract}

Keywords: lesson plan, problem based learning, lectora inspire, learning outcomes, a learning process

\section{Introduction}

Technological developments are taking place very quickly. So people make technological innovations by their fields of expertise [1]. As a result, effective technology products create in all areas. It has changed the paradigm and principles of work in all areas, from the world of information to learning. In the learning process, with the presence of technology products able to deliver students to meet the capacity of the 21st century [2].

A subject that uses technology to support the learning process is physics. According to [3], one of the core competencies needed by a teacher is to communicate and develop the development of a curriculum for the particular area of development, the implementation of educational activities, the development of creatively taught learning topics, and the use of information technology communication. From these requirements and obligations, teachers must be able to assemble teaching topics or innovative learning media, such as printed teaching topics, models, audio teaching topics, audiovisual teaching topics or interactive teaching topics [4], [5].

Lesson plan s need to be developed to improve the quality of education [6]. Besides, renewal in the field of education itself must be supported. One possible solution is to analyze a learning method used in a syllabus [7]. It hoped that this analysis could contribute to the achievement of learning objectives and does not exclude that the analysis can be used as the basis for developing a learning strategy.

Problem-based learning is one of the bridges to creating active learning [8]. This learning begins (1) with researching and solving problems to generate, combine, and generalize knowledge. (2) studentcentered; (3) Activities to combine new knowledge and existing knowledge [9]. The implementation of problem-based learning will be better if there is a learning approach that supports it. In this context, the 
intended approach is the scientific approach. When you learn with a scientific approach, you need a teacher who can prioritize aspects of observation, thinking, and discovery, a scientific approach.

The scientific approach (scientific approach) to learning involves observing, questioning, thinking, trying, and building networks [10]. The learning process touches on three areas: attitudes, knowledge and skills. Improving the quality of learning can be supported through the use of relevant learning tools. So that the use of computers as a learning medium is significant, especially in this challenging time, there are already many learning methods based on information technology. One application that supports the teaching and learning process is Lectora Inspire Software [11].

Lectora Inspire Software is an application program that can be used to create presentations and learning media [12]. Lectora Inspire software lets you create presentations that include text, spreadsheets, images, LP art, audio, video, Flash animations, special effects, 3D effects, and other effects [13]. With the Lectora Inspire software application program, we can prepare a teaching topic, especially in the field of physics lessons for material moments, impulses, and collisions. Although with these benefits, it is still rarely used as a learning medium in schools. For example, some researchers have investigated the use of Lectora Inspire software as a learning tool. Research by [14] shows that the use of ICT-based learning media with the Lectora Inspire software application offers many benefits, including: (a) Lectora Inspire software learning media, if well designed, is a useful learning tool; that can enhance and improve the quality of learning; (b) support individual learning according to students' abilities and can be used as direct feedback; (c) repeating the material as needed without causing boredom; (d) Obstacles to the use of ICT-based learning media with the Lectora Inspire software are human resources. Using ICT-based learning media with the Lectora inspire software can increase the quality of science learning. The use of ICT-based learning media with the Lectora Inspire software application is more interesting for students, and students may become slower in accepting it is, adjust [15].

Based on the description presented, the author is interested in developing a lesson product for the upper school with Lectora Inspira. The goal is to create a Lesson plan using the Lectora Inspire Software-based problem learning model, based on valid, practical and effective impulses and impulses used for learning in high schools.

\section{Theoretical Framework}

Development is a process to develop and validate products used in education, such as an instructional topic for teachers, subjects, media, questions and management systems. Development research is being conducted to solve problems associated with learning tools that are considered problems because they do not exist or do not exist, but that are or do exist but need to be corrected.

Miller and Borg [16] developed 10 steps in the development of learning products, namely: (a) research and information gathering; (b) planning; (c) developing a preliminary product form, (d) preliminary field tests; (e) main revision of the product; (e) field tests; (f) operational product revision; (g) on-site field testing; (h) revision of the final product; and (i) dissemination and implementation.

\section{Lesson plan}

According to the order of the Minister of Education and Culture of the Republic of Indonesia No. 22 of 2016, The Lesson Plan (LP) is a plan for personal learning activities for one or more meetings. The lesson plan developed from the syllabus to guide students' learning activities and achieve basic competency (BC). Each educator in the lesson is required to create a complete and systematic lesson plan that will make the learning interactive, inspiring, entertaining, challenging, efficient, and motivating for student participation. With sufficient room for initiative, creativity, and independence according to their talents and abilities, Interests offered and physical and psychological development of the students. The lesson plan organized according to necessary competencies or subtopics, which held in sessions or more [17].

\section{Problem-Based Learning Model}

Problem-based learning, according to the Ministry of Education and Culture, is a learning approach that highlights contextual issues that encourage students to learn. In classes that use problem-based learning, students work in teams to solve real-world problems.

According to [18] steps to learn a problem-based learning model 
Table 1. Steps to learn a problem-based learning model

\begin{tabular}{ll}
\hline \multicolumn{1}{c}{ Step } & \multicolumn{1}{c}{ The behaviour of the teacher } \\
\hline $\begin{array}{l}\text { Step 1 } \\
\text { Orient the students to } \\
\text { the problem }\end{array}$ & $\begin{array}{l}\text { The teacher explains the learning } \\
\text { objectives and advice or logistics } \\
\text { needed. The teacher motivates } \\
\text { students to participate in selected real } \\
\text { problem-solving activities. }\end{array}$ \\
\hline $\begin{array}{l}\text { Step 2 } \\
\text { Organizing students }\end{array}$ & $\begin{array}{l}\text { The teacher helps the students to } \\
\text { define and organize learning tasks } \\
\text { that relate to problems that oriented } \\
\text { in the previous phase. }\end{array}$ \\
\hline $\begin{array}{l}\text { Step 3 } \\
\text { Do individual and } \\
\text { group examinations }\end{array}$ & $\begin{array}{l}\text { The teacher encourages students to } \\
\text { gather appropriate information and } \\
\text { conduct experiments in order to } \\
\text { achieve the clarity needed to solve } \\
\text { the problems. }\end{array}$ \\
\hline $\begin{array}{l}\text { Step 4 } \\
\text { Develop and present } \\
\text { the work }\end{array}$ & $\begin{array}{l}\text { The teacher helps students share } \\
\text { tasks and plan or prepare suitable } \\
\text { work as a result of problem-solving } \\
\text { in the form of reports, videos, or } \\
\text { models }\end{array}$ \\
\hline $\begin{array}{l}\text { Step 5 } \\
\text { Analyze and evaluate } \\
\text { the problem-solving } \\
\text { process }\end{array}$ & $\begin{array}{l}\text { The teacher helps students to reflect } \\
\text { on or evaluate the problem-solving } \\
\text { process that has been carried out. }\end{array}$ \\
\hline
\end{tabular}

\section{Learning Outcomes}

Winkel [19] explains that learning outcomes achieved by students lead to changes in knowledge or understanding, skills and attitudes. According to Jihad and Haris [20], learning outcomes are skills that children acquire after undergoing learning activities. Learning itself is a process of someone trying to achieve a relatively permanent form of behavioural change. For learning activities or lesson activities, the teacher usually sets learning goals. Students who successfully learn are the ones who succeed in achieving learning goals or teaching goals.

Learning outcomes is a statement that shows how to understand the lessons learned by the students and to be shown at the end of learning [21]. In other words, learning outcomes identify what students know and can do at the end of the learning program. Learning outcomes describe the overall goals or goals of participating in activities during the learning process [22]. In addition, learning outcomes interpreted as describing a result that includes aspects of the knowledge, understanding and abilities that students have acquired during the learning process. Learning outcomes can describe the whole process during the learning process [23].

\section{Software Lectora inspire}

The Lectora Inspire software is a learning media development tool, also called authoring software, developed by Trivantis. Lectora Inspire software is a popular application for creating PowerPoint presentations. The Lectora Inspire software can be used for both online learning (e-learning) and offline (classroom) learning purposes, which can be quickly and easily create. The Lectora Inspire software can be used to combine Flash files, capture videos, combine images and take screenshots.

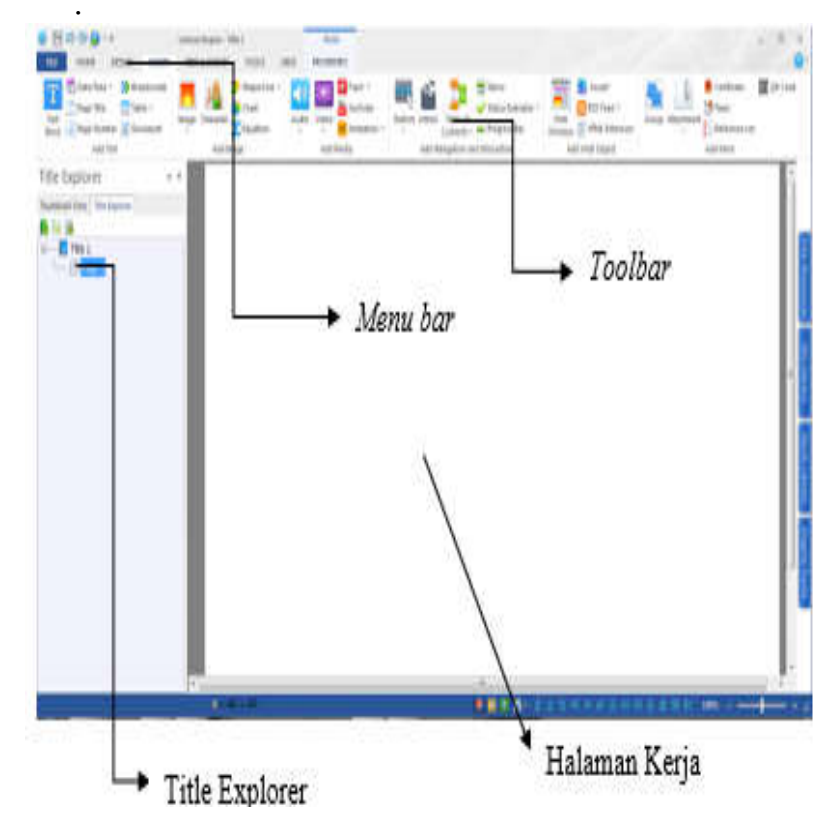

Figure 1. Part of Lectora Inspire Software

\section{Method}

\section{Research Type}

This type of research is a kind of research and development, namely the development of a plan for the implementation of problem-based learning models for learning physics with Lectora Inspire Software on the topic of impulse, momentum and collision for the 2013 A-level curriculum and Master's programs.

\section{Research Design}

This research uses research and development design (Research and Development). This study developed a research design according to [16] from 10 stages of research design, according to Borg and Miller, this study used five stages.

This research uses research and development design (research and development). This study developed a research design according to [16] out of 10 stages of research design according to Borg and Gall, five stages used in this study. 


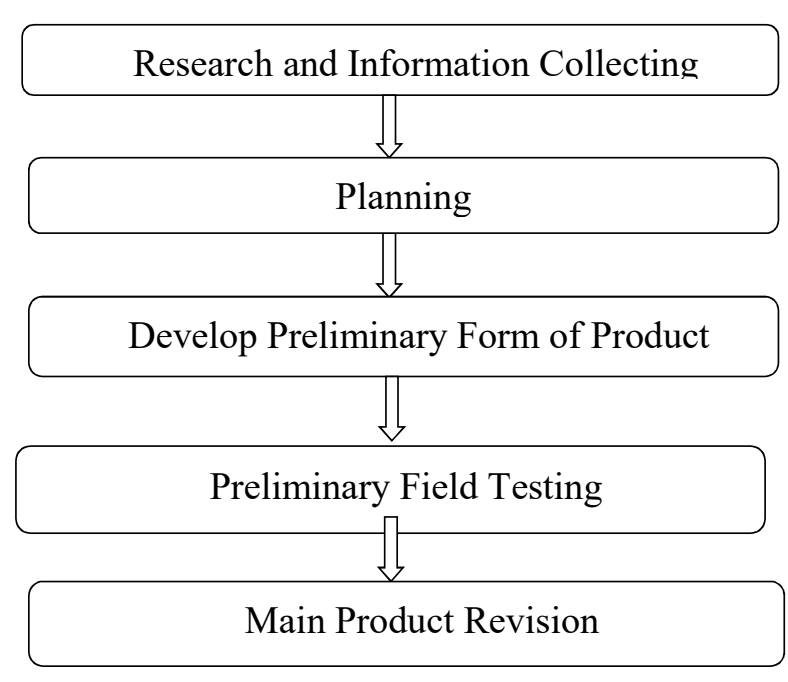

Figure 2. Research stages

Steps - Developing LP software based on Lectora Inspire's Problem-Based Learning Model on Pulse, Impulse, and Collision.

\section{Research Instrument}

The research tool consisted of the instrument of the validity of the learning program plan, consisting of the reliability and reliability of the product.

The practical tool of the learning program plan consists of an observation sheet for learning and a student activity sheet.

The tutorial's effectiveness tool consists of student and teacher questionnaires and completeness indicators.

Data collection techniques and data analysis techniques

1. The data collection techniques include documentation, observation, questionnaires and analysis of the validity and practicability of the Lesson plan using Aiken's V-formula for the calculation of the content.

2. The analysis of the effectiveness of the proposed learning implementation is to analyze the results of student and teacher responses based on the NGain-Value criteria

\section{Terms of Participation For Learning Plans}

According to Nieveen [24], the requirements for an educational product are assessed based on three criteria: validity, the effectiveness of the product and practicability of the product. The Lesson plan with Lectora Inspire Software can be used if the validity level is considered valid. The level of effectiveness and practicality are both used as Lesson plan s used in classroom teaching and learning.

\section{Results and Discussion}

\section{Collect Research Results and Initial Information}

The first phase of developing a Lesson Plan (LP) involves a needs analysis, literature reviews, and the formulation of a learning topic related to the Lectora inspire software. The needs met in this study, namely the lack of use of computer applications to support teaching, are fueling teachers' interest in learning the latest software to help learners learn and implementing information technology (IT) -based learning and implementation plans learning experts have validated that. A literature review recognizes the use of Lectora inspire software as a lesson plan, particularly in terms of the material of impulses, impulses, and collisions. The formulation of the learning topic serves to identify the indicators of the material's necessary competences and to produce a video that will be used for student activities by the 2013 curriculum.

\section{Planning Result}

After analyzing the literature, the course of the lesson plan can be determined according to an essential part of the LP. LP according to Permendikbud no. 22 of 2016 follows the syllabus of 2013. The preparation of the indicators must be consistent with the Ministry of Education and Culture No. 24 of 2016

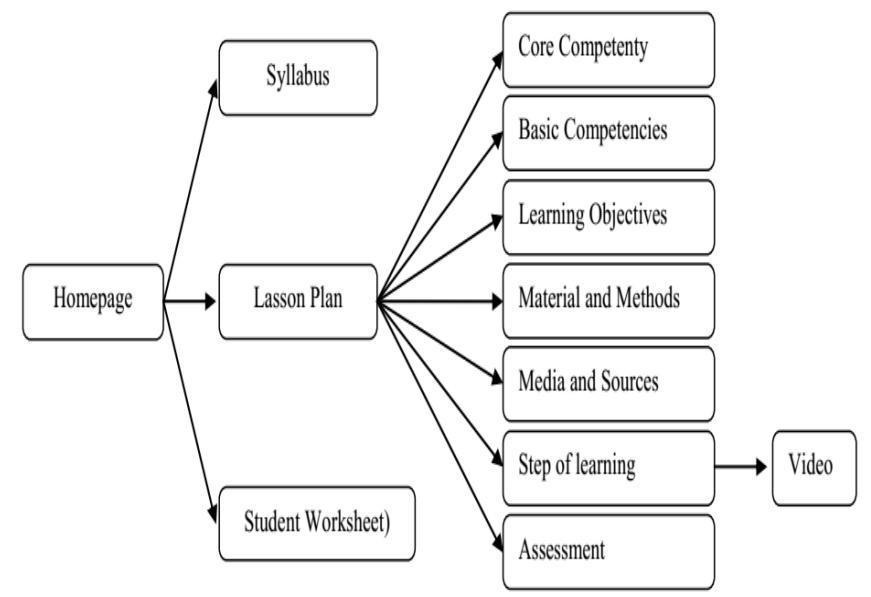

Figure 3. Phase lesson plan development scenario

\section{Result of Development}

The phase of developing the original form of the Lesson plan, which created by the draft design that will be integrated into the Lectora Inspire software. Validate LP, learn implementation plans in Lectora Inspire Software, and preliminary and final test 
Aswal et al.

questions (pretest and post-test). Then make improvements as suggested by the validator.

The design of Lectora Inspire Software in the development of LP physics divided into several parts that contain the essence of an LP. Starting from the home screen, menu, sub-curriculum, sub-LP and other lesson plan $\mathrm{s}$ in the form of Student Worksheet.

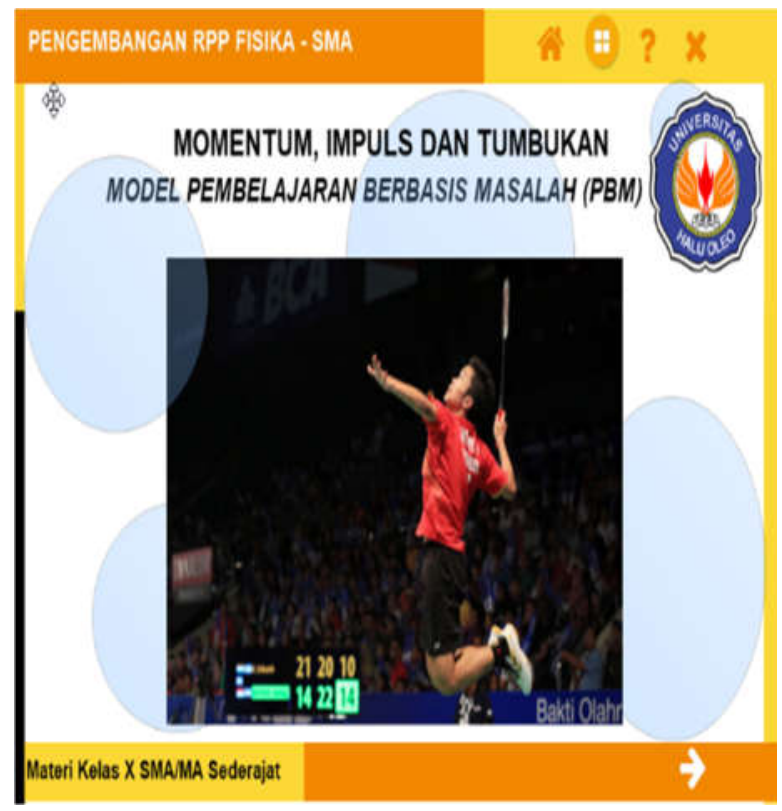

Figure 4. Home screen display

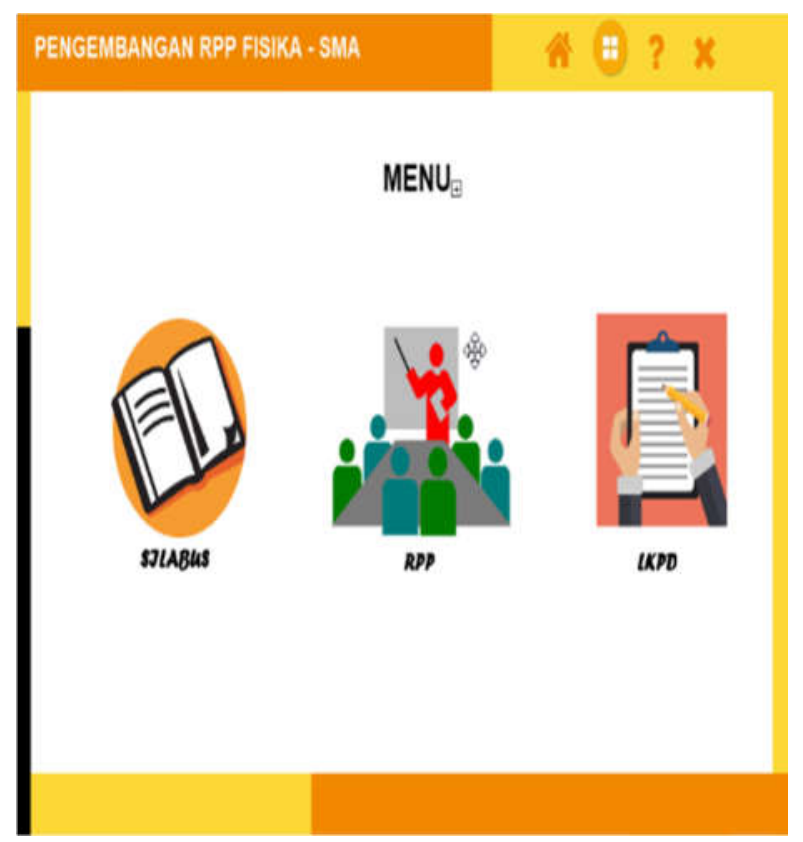

Figure 5. Display menu
Development of Lesson Plan (LP) with Software Lectora Inspire Assisted...

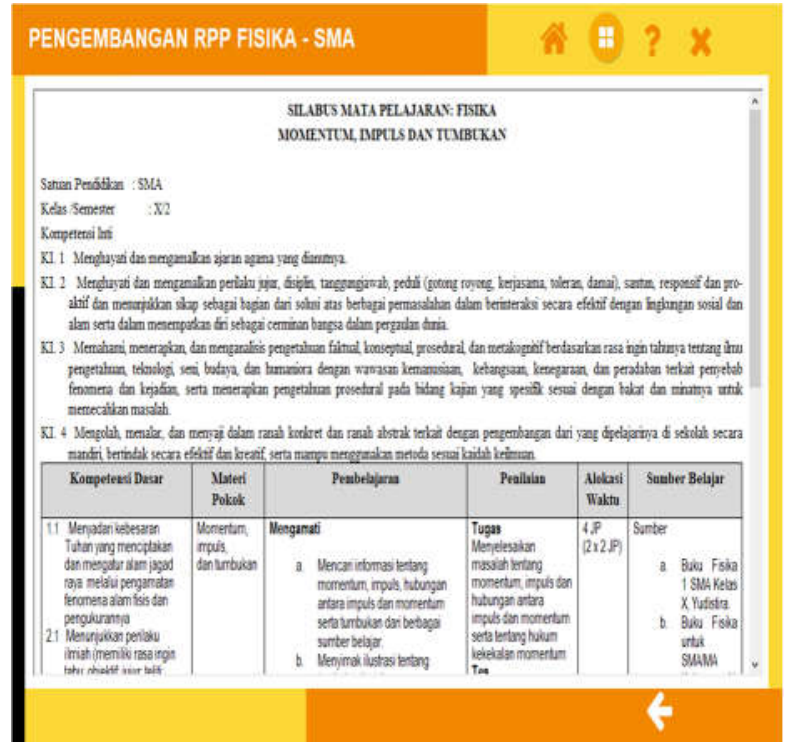

Figure 6. Display submenus syllabus

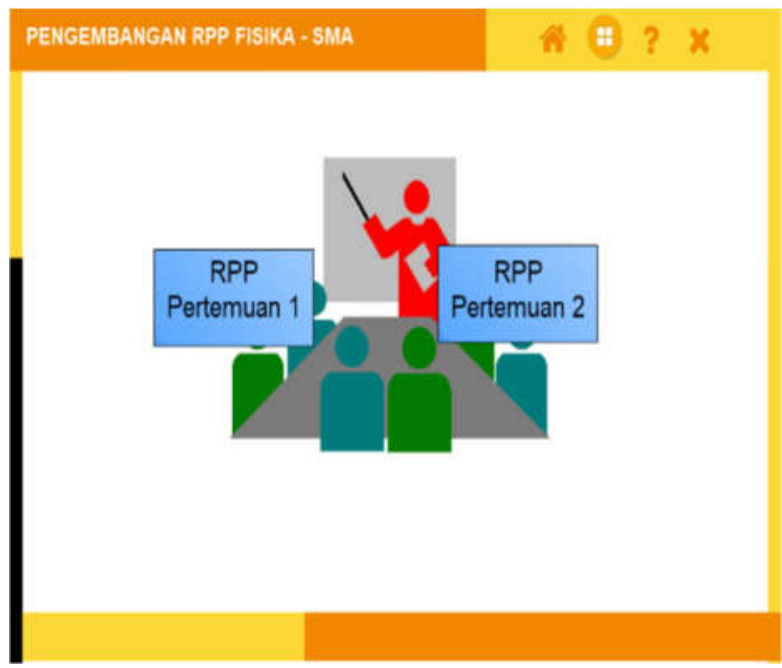

Figure 7. Lesson plan display

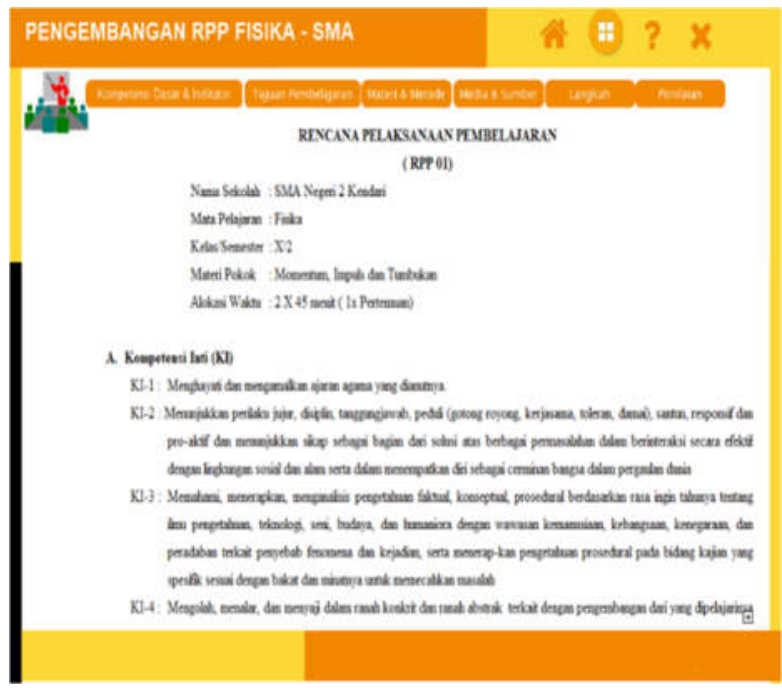

Figure 8. Fill sub-menu lesson plan: Meeting 1 


\section{The Result of Validation Lesson plan}

The results of the validation of the lesson plan shown Table 2

Table 2. The results of the validation of the development planning of the learning implementation with Lectora Inspire

\begin{tabular}{|c|c|c|c|c|c|c|c|c|c|c|c|}
\hline \multirow[t]{2}{*}{ No } & \multirow[t]{2}{*}{ Observed Aspects } & \multicolumn{3}{|c|}{ First Meeting } & \multirow{2}{*}{$\sum \mathbf{S}$} & \multirow{2}{*}{$\begin{array}{c}\text { Aiken's } \\
\text { Validati } \\
\text { on } \\
\end{array}$} & \multicolumn{3}{|c|}{$\begin{array}{l}\text { Second } \\
\text { Meeting }\end{array}$} & \multirow[t]{2}{*}{$\sum \mathbf{S}$} & \multirow{2}{*}{$\begin{array}{c}\text { Aiken's } \\
\text { Validat } \\
\text { e }\end{array}$} \\
\hline & & $V_{1}$ & $\mathbf{V}_{2}$ & $\mathbf{V}_{3}$ & & & $\mathbf{V}_{1}$ & $\mathbf{V}_{2}$ & $V_{3}$ & & \\
\hline & General format & & & & & & & & & & \\
\hline 1 & $\begin{array}{l}\text { Distribution of the material by time } \\
\text { location }\end{array}$ & 4 & 4 & 5 & 10 & 0,83 & 4 & 4 & 5 & 10 & 0,83 \\
\hline \multirow[t]{2}{*}{2} & numbering system & 5 & 5 & 4 & 11 & 0,92 & 5 & 5 & 4 & 11 & 0,92 \\
\hline & content & & & & & & & & & & \\
\hline 1 & Identity is loading & 5 & 5 & 5 & 12 & 1,00 & 5 & 5 & 5 & 12 & 1,00 \\
\hline 2 & Load core potential & 5 & 5 & 5 & 12 & 1,00 & 5 & 5 & 5 & 12 & 1,00 \\
\hline 3 & Basic compatibility is loading & 5 & 5 & 5 & 12 & 1,00 & 5 & 5 & 5 & 12 & 1,00 \\
\hline 4 & charge indicator & 5 & 4 & 5 & 11 & 0,92 & 5 & 4 & 5 & 11 & 0,92 \\
\hline 5 & Load learning objectives & 5 & 4 & 5 & 11 & 0,92 & 5 & 4 & 5 & 11 & 0,92 \\
\hline 6 & Teaching material is being loaded & 4 & 3 & 5 & 9 & 0,75 & 4 & 3 & 5 & 9 & 0,75 \\
\hline 7 & $\begin{array}{l}\text { Contains learning models / approaches / } \\
\text { strategies / methods / techniques }\end{array}$ & 5 & 5 & 5 & 12 & 1,00 & 5 & 5 & 5 & 12 & 1,00 \\
\hline 8 & Learning activities are loaded & 5 & 5 & 5 & 12 & 1,00 & 5 & 5 & 5 & 12 & 1,00 \\
\hline 9 & Loading tools/topic/ learning resources & 5 & 5 & 5 & 12 & 1,00 & 5 & 5 & 5 & 12 & 1,00 \\
\hline \multirow[t]{2}{*}{10} & Reviews are loading & 5 & 3 & 5 & 10 & 0,83 & 5 & 3 & 5 & 10 & 0,83 \\
\hline & Learning Activities & & & & & & & & & & \\
\hline 1 & $\begin{array}{l}\text { The first activity is to generate motivation } \\
\text { and to draw the attention of the students to } \\
\text { participate in the learning process actively. }\end{array}$ & 4 & 4 & 4 & 9 & 0,75 & 4 & 4 & 4 & 9 & 0,75 \\
\hline 2 & $\begin{array}{l}\text { The main activities are interactive, } \\
\text { inspiring, entertaining, challenging and } \\
\text { motivating to participate actively and } \\
\text { provide sufficient space for initiative, } \\
\text { creativity and independence according to } \\
\text { students' talents, interests and physical and } \\
\text { psychological development. }\end{array}$ & 4 & 4 & 4 & 9 & 0,75 & 4 & 4 & 4 & 9 & 0,75 \\
\hline 3 & $\begin{array}{l}\text { The core activities are systematically } \\
\text { carried out through a process of } \\
\text { exploration, preparation and validation }\end{array}$ & 4 & 5 & 3 & 9 & 0,75 & 4 & 5 & 3 & 9 & 0,75 \\
\hline \multirow[t]{2}{*}{4} & $\begin{array}{l}\text { Final activities reflect activities to end } \\
\text { learning activities, create a summary or } \\
\text { conclusion and assessment, and provide } \\
\text { feedback and follow-up }\end{array}$ & 5 & 4 & 4 & 10 & 0,83 & 5 & 4 & 5 & 11 & 0,92 \\
\hline & Learn conformity & & & & & & & & & & \\
\hline 1 & $\begin{array}{l}\text { The accuracy between indicators and } \\
\text { Basic Competence }\end{array}$ & 5 & 5 & 5 & 12 & 1,00 & 5 & 5 & 4 & 11 & 0,92 \\
\hline 2 & $\begin{array}{l}\text { Accuracy between indicators and learning } \\
\text { goals }\end{array}$ & 5 & 4 & 3 & 9 & 0,75 & 5 & 4 & 3 & 9 & 0,75 \\
\hline 3 & $\begin{array}{l}\text { The correctness of the content/material } \\
\text { according to the competency standards of } \\
\text { the curriculum } 2013\end{array}$ & 4 & 4 & 4 & 9 & 0,75 & 5 & 4 & 5 & 11 & 0,92 \\
\hline 4 & $\begin{array}{l}\text { Learning activities are formulated and use } \\
\text { operative words so that they can be easily } \\
\text { performed in the classroom during the } \\
\text { learning process }\end{array}$ & 5 & 4 & 4 & 10 & 0,83 & 5 & 4 & 5 & 11 & 0,92 \\
\hline 5 & $\begin{array}{l}\text { Learning steps after steps problem-based } \\
\text { learning model }\end{array}$ & 5 & 4 & 4 & 10 & 0,83 & 5 & 5 & 4 & 11 & 0,92 \\
\hline 6 & $\begin{array}{l}\text { Compliance with the learning steps of } \\
\text { the scientific learning approach }\end{array}$ & 5 & 5 & 5 & 12 & 1,00 & 5 & 4 & 5 & 11 & 0,92 \\
\hline 7 & $\begin{array}{l}\text { Agreement with the material order of each } \\
\text { meeting }\end{array}$ & 5 & 4 & 4 & 10 & 0,83 & 4 & 4 & 5 & 10 & 0,83 \\
\hline 8 & Compliance with the time allocation used & 4 & 4 & 4 & 9 & 0,75 & 5 & 5 & 4 & 11 & 0,92 \\
\hline 9 & $\begin{array}{l}\text { The PBM model marks the suitability as } \\
\text { LP. }\end{array}$ & 5 & 5 & 5 & 12 & 1,00 & 4 & 5 & 4 & 10 & 0,83 \\
\hline & Language & & & & & & & & & & \\
\hline
\end{tabular}




\begin{tabular}{|c|c|c|c|c|c|c|c|c|c|c|c|}
\hline \multirow[t]{2}{*}{ No } & \multirow[t]{2}{*}{ Observed Aspects } & \multicolumn{3}{|c|}{ First Meeting } & \multirow[t]{2}{*}{$\sum \mathbf{S}$} & \multirow{2}{*}{$\begin{array}{c}\text { Aiken's } \\
\text { Validati } \\
\text { on }\end{array}$} & \multicolumn{3}{|c|}{$\begin{array}{l}\text { Second } \\
\text { Meeting }\end{array}$} & \multirow[t]{2}{*}{$\sum \mathbf{S}$} & \multirow{2}{*}{$\begin{array}{c}\text { Aiken's } \\
\text { Validat } \\
\text { e }\end{array}$} \\
\hline & & $V_{1}$ & $\mathbf{V}_{2}$ & $\mathbf{V}_{3}$ & & & $\mathbf{V}_{1}$ & $\mathbf{V}_{2}$ & $V_{3}$ & & \\
\hline 1 & Grammatical truth & 4 & 5 & 4 & 10 & 0,83 & 4 & 5 & 3 & 9 & 0,75 \\
\hline 2 & The truth of the sentence structure & 4 & 5 & 4 & 10 & 0,83 & 4 & 4 & 4 & 9 & 0,75 \\
\hline 3 & The language used is communicative & 4 & 4 & 4 & 9 & 0,75 & 4 & 4 & 4 & 9 & 0,75 \\
\hline \multicolumn{2}{|r|}{ Results } & & & & 293 & $\mathbf{0 , 8 7}$ & & & & 294 & $\mathbf{0 , 8 8}$ \\
\hline & Total & \multicolumn{10}{|c|}{$\mathbf{0 , 8 7}$} \\
\hline & Category & \multicolumn{10}{|c|}{ Very valid } \\
\hline
\end{tabular}

Note $: \mathrm{V} 1=$ Validator $1 ; \mathrm{V} 2=$ Validator $2 ; \mathrm{V} 3=$ Validator $3 ; \sum \mathrm{s}=$ Aiken total

Inspire The Result of Lesson plan assitet Software Lectora Inspire

Table 3. The Validation Results of the Lectora Inspire Software Assisted Learning Plan

\begin{tabular}{|l|l|r|r|r|c|}
\hline No & \multicolumn{1}{|c|}{ Observed aspects } & $\mathbf{V}_{\mathbf{1}}$ & $\mathbf{V}_{\mathbf{2}}$ & \multicolumn{1}{|c|}{$\begin{array}{c}\text { Aiken } \\
\text { Validity }\end{array}$} \\
\hline & Media quality & & & & \\
\hline 1 & display & 4 & 4 & 6 & 0,75 \\
\hline 2 & Use of buttons & 3 & 5 & 6 & 0,75 \\
\hline 3 & Text type and size & 5 & 3 & 6 & 0,75 \\
\hline 4 & colour composition & 5 & 5 & 8 & 1,00 \\
\hline 5 & Video / audio quality & 4 & 3 & 5 & 0,63 \\
\hline 6 & Ease of speech understanding & 4 & 4 & 6 & 0,75 \\
\hline 7 & Quality of interaction & 4 & 3 & 5 & 0,63 \\
\hline 8 & Attraction and motivation & 5 & 5 & 8 & 1,00 \\
\hline 9 & Cover design attracts users & 5 & 4 & 7 & 0,88 \\
\hline & The program & & & & \\
\hline 1 & navigation & 4 & 3 & 5 & 0,63 \\
\hline 2 & Button consistency & 3 & 3 & 4 & 0,50 \\
\hline 3 & Clarity of the instructions for use & 3 & 4 & 5 & 0,63 \\
\hline 4 & Efficient screen usage & 4 & 3 & 5 & 0,63 \\
\hline 5 & Text efficiency & 5 & 4 & 7 & 0,88 \\
\hline & practicability & & & & \\
\hline 1 & LP-assisted applications are easy to execute & 5 & 3 & 6 & 0,75 \\
\hline 2 & Digital LP can be set according to the user requirement & 5 & 5 & 8 & 1,00 \\
\hline & linguistic & & & & \\
\hline 1 & The language used corresponds to the correct grammar & 4 & 5 & 7 & 0,88 \\
\hline 2 & The sentences used in the text are easy to understand & 4 & 5 & 7 & 0,88 \\
\hline & $\quad$ & & $\mathbf{1 1 1}$ & $\mathbf{0 , 7 7}$ \\
\hline & Final Score & & & \\
\hline
\end{tabular}

Note $: \mathrm{V} 1=$ Validator $1 ; \mathrm{V} 2=$ Validator $2 ; \sum \mathrm{s}=$ Aiken total

\section{Indicator Validity Completion Result}

Table 4. The results of the validation of the indicator mastery test

\begin{tabular}{|c|c|c|c|c|c|c|c|c|c|c|}
\hline \multirow[t]{2}{*}{ No l } & \multicolumn{3}{|c|}{$\begin{array}{l}\text { Content } \\
\text { validity }\end{array}$} & \multirow[t]{2}{*}{$\sum \mathbf{S}$} & \multirow[t]{2}{*}{$\begin{array}{c}\text { Aiken } \\
\text { validity }\end{array}$} & \multicolumn{3}{|c|}{$\begin{array}{c}\text { Validation of } \\
\text { Language and } \\
\text { Writing } \\
\end{array}$} & \multirow[t]{2}{*}{$\sum \mathbf{S}$} & \multirow[t]{2}{*}{ Aiken validity } \\
\hline & $\mathbf{V}_{1}$ & $\mathbf{V}_{2}$ & $V_{3}$ & & & $\mathbf{V}_{1}$ & $\mathbf{V}_{2}$ & $\mathbf{V}_{3}$ & & \\
\hline 1 & 2 & 5 & 3 & 7 & 0,47 & 3 & 5 & 4 & 9 & 0,75 \\
\hline 2 & 3 & 5 & 4 & 9 & 0,60 & 4 & 5 & 4 & 10 & 0,83 \\
\hline 3 & 4 & 5 & 4 & 10 & 0,67 & 4 & 5 & 4 & 10 & 0,83 \\
\hline 4 & 4 & 5 & 5 & 11 & 0,73 & 4 & 5 & 5 & 11 & 0,92 \\
\hline 5 & 5 & 5 & 5 & 12 & 0,80 & 4 & 5 & 5 & 11 & 0,92 \\
\hline 6 & 2 & 5 & 4 & 8 & 0,53 & 3 & 5 & 4 & 9 & 0,75 \\
\hline 7 & 2 & 5 & 4 & 8 & 0,53 & 3 & 5 & 4 & 9 & 0,75 \\
\hline 8 & 2 & 5 & 5 & 9 & 0,60 & 3 & 5 & 5 & 10 & 0,83 \\
\hline \multicolumn{4}{|c|}{ Final score } & 74 & 0,62 & \multicolumn{3}{|c|}{ Final score } & 79 & $\mathbf{0 , 8 2}$ \\
\hline \multicolumn{4}{|c|}{ Category } & \multicolumn{2}{|c|}{ Valid } & \multicolumn{3}{|c|}{ Category } & \multicolumn{2}{|r|}{ Very Valid } \\
\hline
\end{tabular}




\section{Indicator Validity Completion Result}

Table 5. Data observations of student activities

\begin{tabular}{|c|c|c|c|c|c|}
\hline \multirow{2}{*}{ No } & \multirow{2}{*}{ Observed aspects } & \multicolumn{2}{|c|}{ First Meeting } & \multicolumn{2}{|c|}{ Second Meeting } \\
\hline & & Average & Category & Average & Category \\
\hline 1 & Introduction & 0,94 & VW & 0,97 & VW \\
\hline 2 & problem orientation & 0,94 & $\mathrm{VW}$ & 0,94 & VW \\
\hline 3 & Organize students & 0,78 & W & 0,84 & VW \\
\hline 4 & Senior group examinations & 0,78 & $\mathrm{~W}$ & 0,88 & VW \\
\hline 5 & Develop and present results & 0,88 & VW & 0,88 & VW \\
\hline 6 & Formulate conclusions & 1,00 & VW & 0,94 & VW \\
\hline 7 & Closing & 0,96 & VW & 0,83 & VW \\
\hline & Score & $\mathbf{0 , 8 9}$ & VW & $\mathbf{0 , 8 9}$ & SB \\
\hline & Final Score & \multicolumn{4}{|c|}{$\mathbf{0 , 8 9}$} \\
\hline & Category & & VV & & \\
\hline
\end{tabular}

Note: $\mathrm{W}=$ Well ; VW = Very Well

The Result os Student Response

Table 6. Student response result

\begin{tabular}{|c|c|c|c|c|c|c|c|c|}
\hline \multirow{2}{*}{ No } & \multirow{2}{*}{ Statement } & VW & $\mathbf{V}$ & WE & NW & NVW & \multirow{2}{*}{$\begin{array}{l}\text { Percentage } \\
(\%)\end{array}$} & \multirow{2}{*}{ Category } \\
\hline & & 5 & 4 & 3 & 2 & 1 & & \\
\hline 1. & $\begin{array}{l}\text { Learning activities with the Lectora Inspire Software- } \\
\text { supported Problem Based Learning (PBL) model are fun. }\end{array}$ & 17 & 10 & 0 & 0 & 0 & 92,59 & VW \\
\hline 2. & $\begin{array}{l}\text { Physics learning activities with the Lectora Inspire } \\
\text { Software-supported Problem Based Learning (PBL) } \\
\text { model are easy to follow. }\end{array}$ & 16 & 8 & 3 & 0 & 0 & 89,63 & VW \\
\hline 3. & $\begin{array}{l}\text { Physical learning with the Lectora Inspire Software- } \\
\text { supported Problem Based Learning (PBL) model helps } \\
\text { me better understand the material, both conceptually and } \\
\text { mathematically. }\end{array}$ & 16 & 6 & 4 & 1 & 0 & 87,40 & VW \\
\hline 4. & $\begin{array}{l}\text { I am interested in learning physics with the Lectora } \\
\text { Inspire Problem-Based Learning Model (PBL) }\end{array}$ & 14 & 12 & 1 & 0 & 0 & 89,63 & VW \\
\hline 5. & $\begin{array}{l}\text { Learning physics with the Lectora Inspire Software- } \\
\text { supported Problem Based Learning (PBL) model } \\
\text { encourages me to learn better than usual. }\end{array}$ & 16 & 6 & 5 & 0 & 0 & 88,15 & VW \\
\hline 6. & $\begin{array}{l}\text { With the Problem Based Learning (PBM) model } \\
\text { supported by Lectora Inspire Software, I am actively } \\
\text { involved in group learning in physics learning }\end{array}$ & 14 & 9 & 4 & 0 & 0 & 87,41 & VW \\
\hline 7. & $\begin{array}{l}\text { Learning physics with the Lectora Inspire Software- } \\
\text { supported Problem Based Learning (PBL) model must be } \\
\text { used as students need to be more active in absorbing } \\
\text { knowledge. }\end{array}$ & 13 & 11 & 3 & 0 & 0 & 87,41 & VW \\
\hline 8. & $\begin{array}{l}\text { The physical learning process with the Lectora Inspire } \\
\text { Software-supported Problem Based Learning (PBL) } \\
\text { model on impulse, momentum and collision material } \\
\text { makes it easy for me to remember the material }\end{array}$ & 12 & 14 & 1 & 0 & 0 & 88,15 & VW \\
\hline 9. & $\begin{array}{l}\text { Learning in small groups in physical learning with the } \\
\text { Problem Based Learning (PBM) model supported by } \\
\text { Lectora Inspire Software is better because it can discuss } \\
\text { with group friends, exchange ideas and thoughts }\end{array}$ & 16 & 11 & 0 & 0 & 0 & 91,85 & VW \\
\hline 10 & $\begin{array}{l}\text { I think that after attending physics learning with the } \\
\text { Problem Based Learning Model (PBL Model) supported } \\
\text { by Lectora Inspire Software, there are advances in physics } \\
\text { learning as there is a lot of learning experience }\end{array}$ & 15 & 8 & 4 & 0 & 0 & 88,15 & VW \\
\hline & Average & & & & & & 89,04 & VW \\
\hline
\end{tabular}

Note : VW = Very Well; W = Well; WE= Well enough; NW- Not Well; NVW= Not Very Well 


\section{Teacher Response Data on Learning Implementation Lesson plan}

Table 7. The Results of teacher response

\begin{tabular}{|c|c|c|c|c|}
\hline No & & & $\begin{array}{c}\text { Item Value } \\
\text { Percentage }(\%)\end{array}$ & Category \\
\hline 1 & $\begin{array}{l}\text { The LP (Lesson plan ) Problem Based Learning (PBL) model supported } \\
\text { by Lectora Inspire Software is easy to implement }\end{array}$ & 4 & 80 & Well \\
\hline 2 & $\begin{array}{l}\text { Supported by Lectora Inspire Software, the LP (Lesson plan ) Problem } \\
\text { Based Learning (PBL) model uses easy-to-understand language }\end{array}$ & 5 & 100 & Very well \\
\hline 3 & $\begin{array}{l}\text { The Problem Modeled Learning LP (Lesson plan ) physics model, } \\
\text { which is supported by Lectora Inspire Software, can support IT-based } \\
\text { learning }\end{array}$ & 5 & 100 & Well \\
\hline 4 & $\begin{array}{l}\text { The learning material in the LP Problem Based Learning (PBL) model } \\
\text { supported by Lectora Inspire Software will be presented coherently }\end{array}$ & 4 & 80 & Well \\
\hline 5 & The presented material is material that included in necessary skills & 5 & 100 & Very well \\
\hline 6 & Learning indicators correspond to the necessary competencies & 5 & 100 & Very well \\
\hline 7 & The presented material corresponds to the learning indicators & 4 & 80 & Well \\
\hline 8 & The LP component is displayed coherently and clearly & 4 & 80 & Well \\
\hline 9 & $\begin{array}{l}\text { The language used in LP (Lesson plan ) complies with the Indonesian } \\
\text { language rules }\end{array}$ & 4 & 80 & Well \\
\hline 10 & Levels that listed in LP (Lesson plan ) & 5 & 100 & Very well \\
\hline 11 & $\begin{array}{l}\text { The sequence of learning activities according to the steps of the learning } \\
\text { model of Problem Based Learning (PBL) }\end{array}$ & 5 & 100 & Very well \\
\hline 12 & $\begin{array}{l}\text { the sequence of learning activities according to the steps of the scientific } \\
\text { approach }\end{array}$ & 4 & 80 & Well \\
\hline 13 & $\begin{array}{l}\text { The specified time allocation is useful for performing various activities } \\
\text { in LP }\end{array}$ & 4 & 80 & Well \\
\hline 14 & $\begin{array}{l}\text { The LP Problem Based Learning (PBL) model supported by Lectora } \\
\text { Inspire Software is easy to implement }\end{array}$ & 5 & 100 & Very well \\
\hline 15 & $\begin{array}{l}\text { The LP Problem Based Learning (PBL) model supported by Lectora } \\
\text { Inspire Software is constructive in preparing the learning process } \\
\text { scenario. }\end{array}$ & 4 & 80 & Very well \\
\hline \multicolumn{2}{|r|}{ Average } & & 88 & Very well \\
\hline
\end{tabular}

\section{Student Learning Outcomes}

Table 8. Student learning outcomes

\begin{tabular}{|c|l|c|c|c|c|c|c|}
\hline \multirow{2}{*}{ No } & \multirow{2}{*}{ Name } & \multicolumn{2}{|c|}{ Pre Test } & \multicolumn{2}{|c|}{ Post Test } & \multicolumn{2}{c|}{ Increased } \\
\cline { 3 - 8 } & & Score & Category & Score & Kategori & $<\boldsymbol{g}$ Score \\
\hline 1 & ATR & 34 & Not Complete & 78 & 1 & ATR & 34 \\
\hline 2 & AFB & 27 & Not Complete & 78 & 2 & AFB & 27 \\
\hline 3 & ABR & 32 & Not Complete & 72 & 3 & ABR & 32 \\
\hline 4 & AENG & 34 & Not Complete & 83 & 4 & AENG & 34 \\
\hline 5 & AP & 36 & Not Complete & 72 & 5 & AP & 36 \\
\hline 6 & AAPS & 60 & Not Complete & 83 & 6 & AAPS & 60 \\
\hline 7 & FI & 27 & Not Complete & 83 & 7 & FI & 27 \\
\hline 8 & FF & 32 & Not Complete & 78 & 8 & FF & 32 \\
\hline 9 & LAW & 32 & Not Complete & 69 & 9 & LAW & 32 \\
\hline 10 & MDA & 50 & Not Complete & 69 & 10 & MDA & 50 \\
\hline 11 & MFD & 48 & Not Complete & 83 & 11 & MFD & 48 \\
\hline 12 & MIN & 32 & Not Complete & 76 & 12 & MIN & 32 \\
\hline 13 & MI & 34 & Not Complete & 67 & 13 & MI & 34 \\
\hline 14 & NKS & 30 & Not Complete & 75 & 14 & NKS & 30 \\
\hline 15 & NAP & 48 & Not Complete & 83 & 15 & NAP & 48 \\
\hline 16 & NF & 45 & Not Complete & 75 & 16 & NF & 45 \\
\hline 17 & NSFA & 32 & Not Complete & 83 & 17 & NSFA & 32 \\
\hline 18 & N & 38 & Not Complete & 81 & 18 & N & 38 \\
\hline 19 & N & 48 & Not Complete & 79 & 19 & N & 48 \\
\hline 20 & N & 48 & Not Complete & 67 & 20 & N & 48 \\
\hline 21 & RSR & 42 & Not Complete & 76 & 21 & RSR & 42 \\
\hline 22 & SAJ & 34 & Not Complete & 77 & 22 & SAJ & 34 \\
\hline 23 & UI & 45 & Not Complete & 75 & 23 & UI & 45 \\
\hline 24 & WA & 50 & Not Complete & 83 & 24 & WA & 50 \\
\hline
\end{tabular}




\begin{tabular}{|c|l|c|c|c|c|c|c|}
\hline \multirow{2}{*}{ No } & \multirow{2}{*}{ Name } & \multicolumn{2}{|c|}{ Pre Test } & \multicolumn{2}{c|}{ Post Test } & \multicolumn{2}{c|}{ Increased } \\
\cline { 3 - 7 } & & Score & Category & Score & Kategori & $<\boldsymbol{g}>$ & Score \\
\hline 25 & WOID & 36 & Not Complete & 83 & 25 & WOID & 36 \\
\hline 26 & Y & 27 & Not Complete & 74 & 26 & Y & 27 \\
\hline 27 & YZK & 45 & Not Complete & 76 & 27 & YZK & 45 \\
\hline \multicolumn{2}{|c|}{ Average } & $\mathbf{3 8 , 7}$ & Not Complete & $\mathbf{7 6 , 9}$ & Complete & Average & $\mathbf{3 8 , 7}$ \\
\hline
\end{tabular}

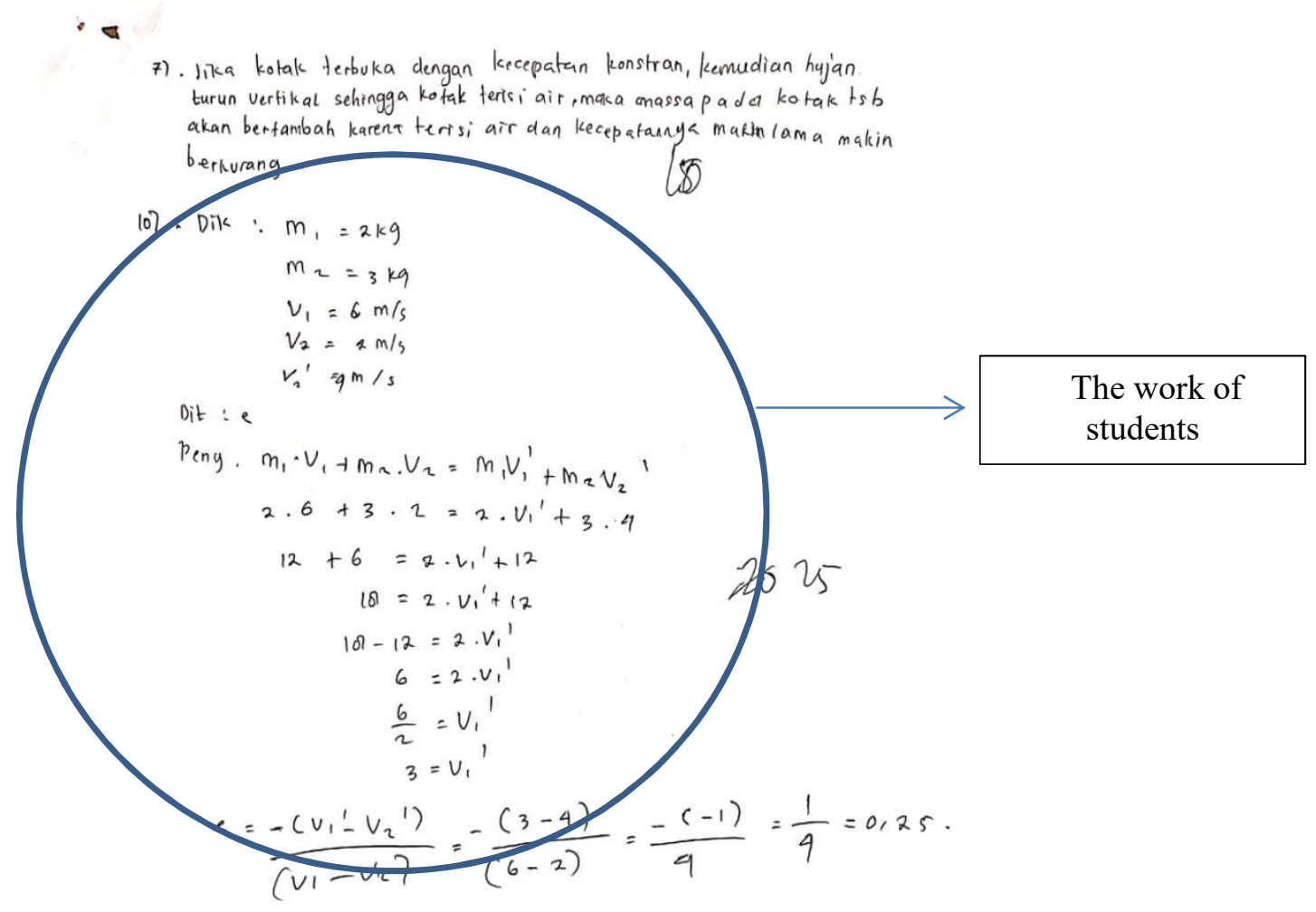

Figure 10. The results of student work on the topic being taught

\section{Learn Implementation Data}

Table 9. The Results of learning implementation

\begin{tabular}{|c|l|c|c|c|c|}
\hline \multirow{2}{*}{ No } & \multirow{2}{*}{ Observed aspects } & \multicolumn{2}{c|}{ First Meeting } & \multicolumn{2}{c|}{ Second Meeting } \\
\cline { 3 - 6 } & & Score & Category & Score & Category \\
\hline 1 & preparations & 0,89 & VW & 0,93 & VW \\
\hline 2 & problem orientation & 0,91 & VW & 0,91 & VW \\
\hline 3 & Organize students & 1,00 & VW & 1,00 & VW \\
\hline 4 & Senior group examinations & 0,93 & VW & 1,00 & VW \\
\hline 5 & Develop and present results & 0,75 & W & 1,00 & VW \\
\hline 6 & Formulate conclusions & 0,83 & VW & 0,87 & VW \\
\hline 7 & Closing & 0,83 & VW & 0,87 & VW \\
\hline \multicolumn{2}{c}{ Score } & $\mathbf{0 , 8 9}$ & VW & $\mathbf{0 , 9 3}$ & SW \\
\hline \multicolumn{2}{c|}{$\mathbf{0 , 9 1}$} & \multicolumn{3}{c|}{ SW } \\
\hline
\end{tabular}

Note: VW = Very Well, W=Well

Based on observations from preliminary activities, content activities marked by problembased learning steps, and closing activities, the total value of the first meeting was 0.89 , which was very good categorized, and the total value of the second meeting was 0.93 which was very well categorized. When the total meeting calculated, the result is 0.91 , which is very well categorized.
The lesson plan (LP) is a plan for personal learning activities for one or more meetings. The lesson plan has been developed from the syllabus to guide students' learning activities and achieve basic competency (BC). LP uses Lectora Inspire software to improve students' learning outcomes in the classroom and to assist teachers with teaching and learning activities in the classroom. The evaluation or critical to the success of this product will be 
assessed in terms of the validity, effectiveness and practicability of the Lectora Inspire-supported Lesson plan.

LP validation with a problem-based learning model supported by Lectora Inspire Software on momentum, impulse, and impact topic at the SHS / Islamic senior high school level

In the product validation phase, the experts are executed in this case to obtain validation results. The result of the validation is expert considerations on the developed learning products. The validation technique used by experts to make corrections to the learning product is then repaired or revised in the LP and then. Three types of validation are performed, namely LP validation by education experts, LP validation by media experts (IT experts), and validation of the indicator completeness test.

Based on observations from preliminary activities, content activities marked by PBM's steps, and closing activities, the total value of the first meeting was 0.89 , which was very good categorized, and the total value of the second meeting was 0.93 which was very well categorized. When the total meeting calculated, the result is 0.91 , which is very well categorized.

The Lesson Plan (LP) is a plan for personal learning activities for one or more meetings. The lesson plan has been developed from the syllabus to guide students' learning activities and achieve basic competency (BC). LP uses Lectora Inspire software to improve students' learning outcomes in the classroom and to assist teachers with teaching and learning activities in the classroom. The evaluation or critical to the success of this product will be assessed in terms of the validity, effectiveness and practicability of the Lectora Inspire-supported Lesson plan.

LP validation with a problem-based learning model supported by Lectora Inspire Software on momentum, impulse, and impact topic at the SHS / Islamic senior high school level

In the product validation phase, the experts are executed in this case to obtain validation results. The result of the validation is expert considerations on the developed learning products. The validation technique used by experts to make corrections to the learning product is then repaired or revised in the LP and then. Three types of validation are performed, namely LP validation by education experts, LP validation by media experts (IT experts), and validation of the indicator completeness test.

\section{LP validation by education experts}

This LP validation is performed to obtain a valid LP based on several learning education experts. The researchers validated three education experts. Based on Table 2, aspects of the assessment include the general format of the lesson plan, the content, the learning activities, the learning skills, and the language of the Lesson Plan (LP). According to the table, validation of the results at the LP of the first meeting has a total value of 0.87 for each sub-aspect evaluation and a total value of $0.88 \mathrm{LP}$ of the second meeting. It allows the validation results to be retrieved at the first meeting in the very valid category and the second meeting in the very valid category. The total score obtained is based on the results of 0.87 in the very valid category, so that several education experts have confirmed that the LP has a degree of validity that can be used in teaching and learning in schools. In addition, there are several expert suggestions in Table 5, which then repaired or revised.

\section{Validation of LP products by media experts}

The validation of the LP by media experts focuses on the completeness and presentation of the LP in the media supported by Lectora Inspire Software (LIS). It to help the teacher present and explain the purpose of learning for the students in the class. During the validation phase of this LP, the validator evaluates the entire LP product in the Lectora Inspire software. Based on Table 3, validation evaluations by media experts include the quality of LP media, programs, practicability, and language in SLI-supported media. The results of the validation show the number 0.77 so that it falls into the correct category. Although validated by both validators in the field of media professionals. However, there are some constructive suggestions from media experts, which can be seen in Table 6, which revised before being tested in schools.

\section{Validity check for completeness of the indicator}

The Indicator Completeness Test is a tool to find out how students can understand each indicator. The test used is an initial test (pre-test) and a final test (post-test) to obtain information about the students' learning outcomes before and after learning. Based on Table 4.4, the rating or validation assessed by content, language and script. The result of the validation is 0.62 for content validation, so it is considered valid, and 0.82 for language validation and writing is considered very 
valid. However, there are some suggestions from the validator that listed in Table 4.7. It will be revised to refine further the concepts that students receive through learning indicators, particularly in terms of topic momentum, impulses, and collisions.

The practicality of LP with the problem-based learning model for momentum, impulse and impact material supported by Lectora Inspire Software at the SHS / Islamic senior high school level.

The practical test of the Lesson plan, which examined from a variety of perspectives, namely the observation of the learning implementation and the observation of the students' activities in the teaching and learning process. Based on the results of tests conducted on 27 XI IPA 6 students from Senior High School 2 Kendari, the Lectora Inspiresupported learning plan can be used in the classroom. It is evident from the observation of the learning implementation and observation of student activities, which divided into seven sections: Introduction, content according to Problem Based Learning (PBL) consists of problem orientation, organizing the students, conducting the group inquiry, developing and presenting the results, and formulating conclusions and complete. According to 2 teachers from Senior High School 2 Kendari, the total score at the first and second meetings was 0.89 or could be considered very good. In addition, there is a final total score of 0.91 for the observation of student activities, or it can be very well categorized.

The effectiveness of LP with the problem-based learning model in the field of pulses, impulses and collisions at the SHS / ISHS level supported by Lectora Inspire Software. In addition, an efficacy test is performed to evaluate the development of a good LP product. The Product Effectiveness Test will provide information on the effectiveness of product development when applied in the field learning process. The efficacy test in this study covers students 'and teachers' answers in the form of student questionnaires and learning outcomes for the learning process.

The effectiveness of a product based on students' reactions to the implementation of classroom learning. From the results of the survey of students, consisting of 10 statements selected by 27 students. Thus, the results obtained with each point are $92.59 \%, 89.63 \%, 87.40 \%, 89.63 \%$, $88.15 \%, 87.41 \%, 87.41 \%, 88.15 \%, 91,85 \%$ and $88.15 \%$ with an average of $89.04 \%$, which are overall in the very good category. As for the reaction of teachers who perform or implement LP products. Based on data from 15 statements, the average score is $88 \%$ or can be very well categorized.

To assess the success of the learning outcomes an initial test (pre-test) and a final test (post-test) performed and an assessment of the improvement (profit analysis) of the results of each student made. Although the subject matter of the study conducted for class XI students who received the material in class X, the first test generally yielded a full student of all students, with an average overall score of 38.7 students. The resulting average is still below the standard completeness score of 75 for physics subjects after learning for two sessions about material impulse, impulses and collisions. The final test is then performed to determine student development after learning. At the end test, students scored a total of 25 students out of 27 students, with an overall score of 76.9. Student learning outcomes averaged a gain of 0.62 , which can be considered moderate.

Based on the research findings, Lectora Inspire is an active program for creating Lesson plan $\mathrm{s}$ and electronic learning development software (elearning) that is relatively easy to apply or can be applied because it does not require a sophisticated understanding of the programming languages. This software can also create implementation plans for learning in the form of e-lesson plans that can publish on the Internet. Using Lectora inspire makes the theme as attractive as possible, it can display videos and animated images on the subject, and the teacher can create test material in it. The learning process becomes more entertaining and meaningful, improving students' learning performance.

In general, students feel motivated to learn after seeing the learning steps structured in the Lectora Inspire Software-supported Lesson plan. Through appropriate videos on the learning topic, students are more interested in learning than just reading in printed books and articles. The activities carried out to strengthen the understanding of the material impulse, the impulses, and the collisions.

\section{CONCLUSION}

Based on the description that has been described, the following conclusions can be drawn: (1). The implementation plan of Lectora Inspire software learning on the subject matter of momentum, impulses and collisions that have developed has gone through several stages of validity testing. A decision obtained that the lesson plan assisted by Lectora Inspire Software that developed was valid to be used. (2) The Lectora Inspire Software rocky 
learning implementation plan on the subject matter of momentum, impulses and collisions has carried out practical tests by observing the implementation of learning and observing the activities of students, which are categorized very well. (3) The effectiveness of Lectora Inspire's Lesson plan (LP) on the subject matter of momentum, impulses and collisions has led to increased student learning outcomes and student responses and teacher responses to the teaching and learning process by averaging an outstanding category.

\section{Acknowledgment}

The author would like thanks to the Department of Physics Education at the University of Halu Oleo for supporting this research so that this research can be completed. Moreover, thanks to Head of Senior High School 2 Kendari for all the facilities and time during the research process so that the research can be done correctly.

\section{Reference}

[1] C. Angeli and N. Valanides, "Epistemological and methodological issues for the conceptualization, development, and assessment of ICT-TPCK: Advances in technological pedagogical content knowledge (TPCK)," Comput. Educ., vol. 52, no. 1, pp. 154-168, Jan. 2009.

[2] R. S. Malik, "Educational Challenges in 21 st Century and sustainable Development," J. Sustain. Dev. Educ. Res., vol. 2, no. 1, p. 9, May 2018.

[3] A. Prastowo, Panduan Kreatif Membuat Bahan Ajar Inovatif. Yogyakarta: Diva Press, 2011.

[4] A. J. Al-Khalifah, "Teachers' use of audiovisual media for teaching and learning in Kuwait public schools, the influence of teacher training colleges and the role of the school library in media provision," Loughborough University, 1994.

[5] B. Ghirardini, E-learning methodologies: A guide for designing and developing e-learning courses. 2011.

[6] M. Yoshida, "Mathematics lesson study in the United States," Int. J. Lesson Learn. Stud., vol. 1, no. 2, pp. 140152, May 2012.

[7] C. Suter, Describing and evaluating a syllabus in a context of compulsory secondary schooling. Birmingham: University of Birmingham, 2001.

[8] A. Shepherd and B. Cosgrif, "Problem-Based Learning: A Bridge between Planning Education and Planning Practice," J. Plan. Educ. Res., vol. 17, no. 4, pp. 348-357, Jun. 1998.

[9] S. M. Bridges, "Problem-Based Learning in Teacher Education," Interdiscip. J. Probl. Learn., vol. 13, no. 1, Feb. 2019

[10] N. Nana, "The Implementation of POE2WE Model Using Scientific Approach in Linear Learning in Senior High School," Pros. SNFA (Seminar Nas. Fis. dan Apl., vol. 3, p. 196, Feb. 2019

[11] S. Noor-ul-Amin, "An Effective Use of ICT for Education and Learning by Drawing on Worldwide Knowledge, Research, and Experience." Department of Education University of Kashmir, 2012.
[12] N. R. Akbarini, W. Murtini, and A. N. Rahmanto, "The effect of Lectora inspire-based interactive learning media in vocational high school," J. Pendidik. Vokasi, vol. 8, no. 1, p. 78, Feb. 2018.

[13] U. Cahyana, Y. Yusmaniar, and I. Komala, "The Development of Lectora Inspire Media With Scientific Based Approach For Teaching Reduction-Oxidation Reaction Through Professional Learning Community," in ICERI2016 Proceedings, 2016.

[14] E. Widiastut, "Penerapan Media Pembelajaran Berbasis ICT Dengan aplikasi Lectora Inspire dalam Pembelajaran IPA (Studi Kasus Di SD Negeri Baran I Kecamatan Rongkap, Kabupaten Gunungkidul)," Universitas Sebelas Maret, 2013.

[15] K. B. N. Noor, "Development of Interactive Learning Media Based on Computer Using Lectora Inspire Software on Basic Accounting Subject to Improve Student Learning Motivation of Class X AK 1 in SMK Muhammadiyah 1 Yogyakarta," Yogyakarta State University, 2018.

[16] D. M. Miller, "Book Reviews: Borg,Walter R. Educational Research: An Introduction," Am. Educ. Res. J., vol. 1, no. 1, pp. 75-77, Jan. 1964.

[17] V. Cicek and H. Tok, "Effective Use of Lesson Plans to Enhance Education in U.S. and Turkish Kindergarten thru 12th Grade Public School System: A Comparative Study," Int. J. Teach. Educ., vol. 2, no. 2, pp. 10-20, 2014.

[18] K. Agustina, W. H. Kristiyanto, and D. Noviandini, "Learning Design of Problem Based Learning Model Based on Recommendations of Sintax Study and Contents Issues on Physics Impulse Materials with Experimental Activities," Int. J. Act. Learn., vol. 2, no. 2, pp. 68-81, 2017

[19] W. S. Winkel, Psikologi Pembelajaran. Yogyakart: Media Abadi, 2004.

[20] Jihat and Haris, Sosiologi Pendidikan. Jakarta: PT. Grasindo, 2008.

[21] S. Fayanto, M. Misrawati, D. Sulisworo, H. F. N. Istiqomah, and L. Sukariasih, "The Implementation of Multimedia on Physics Learning Based on Direct Instruction Model in The Topic of Light," Indones. J. Learn. Educ. Couns., vol. 1, no. 2, pp. 124-132, Feb. 2019.

[22] F. Fatmawati, L. Sukariasih, S. Fayanto, and H. Retnawati, "Investigating the Effectiveness of Inquiry Learning and Direct Learning Models Toward Physics Learning," in Proceedings of the First International Conference on Progressive Civil Society (ICONPROCS 2019), 2019

[23] S. Fayanto, M. Musria, E. Erniwati, L. Sukariasih, and H. Hunaidah, "Implementation of Quantum Teaching Model On Improving Physics Learning Outcomes In The Cognitive Domain At Junior High School," IJIS Edu Indones. J. Integr. Sci. Educ., vol. 1, no. 2, pp. 131-138, Jul. 2019.

[24] N. Nieveen, "Prototyping to Reach Product Quality," in Design Approaches and Tools in Education and Training, Dordrecht: Springer Netherlands, 1999, pp. $125-135$. 